\title{
PENGGUNAAN DANA DESA DI DESA TASIK JUANG KABUPATEN INDRAGIRI HULU
}

\author{
Larasati Hamidah $^{1}$, Rido Parulian Panjaitan ${ }^{2}$ \\ 1,2Politeknik Keuangan Negara STAN, larasatihamidah7@gmail.com, \\ rido.panjaitan@pknstan.ac.id
}

\begin{abstract}
ABSTRAK
Penelitian ini mengidentifikasi penggunaan dana desa dengan pertimbangan utama bahwa dana desa berdampak besar dan signifikan terhadap pembangunan desa di Indonesia. Dengan mencakup penggunaan dana desa di Desa Tasik Juang Kecamatan Lubuk Batu Jaya Kabupaten Indragiri Hulu pada tahun 2018-2020, penelitian ini bertujuan untuk mengetahui implementasi penggunaan dana desa, serta dampak penggunaan dana desa bagi masyarakat setempat. Penelitian ini menggunakan metode penelitian kualitatif dengan menelaah data dan informasi dari berbagai sumber kepustakaan yang relevan serta melakukan wawancara kepada narasumber yang terkait dengan penggunaan dana desa. Penelitian ini menggunakan alat analisis logic model. Hasil dari penelitian ini menunjukkan bahwa implementasi dana desa pada tahun 2018-2020 dialokasikan pada 4 bidang yaitu bidang pembangunan desa, pemberdayaan masyarakat, pembinaan masyarakat, dan penanggulangan bencana, darurat, dan mendesak. Secara umum, implementasi dana desa pada tahun 2018-2020 berdampak positf bagi masyarakat terutama pada bidang pembangunan desa.
\end{abstract}

Kata Kunci: Dana desa; penggunaan; implementasi; logic model; dampak.

\begin{abstract}
This study identifies the use of village fund by considering that village fund has huge and significant impact on village development in Indonesia. By covering the use of village fund in Tasik Juang Village, Lubuk Batu Jaya District, Indragiri Hulu Regency in 2018-2020, this study aims to determine the implementation of the use of village fund and the impact of the use of village fund for local communities. This research uses qualitative research method by examining data and information from various relevant literature sources and conducting interviews with resource persons related to the use of village fund. This study uses logic model analysis tool. The results of this study indicate that the implementation of village fund in 2018-2020 is allocated to 4 fields, namely village development, community empowerment, community development, and disaster, emergency, and urgent management. In general, the implementation of village fund in 2018-2020 has a positive impact on the community, especially in the field of village development.
\end{abstract}

Keywords: Village fund; utilization; implementation; logic model; impact.

Naskah diterima : 16-08-2021, Naskah dipublikasikan : 28-09-2021 


\section{PENDAHULUAN}

Kebijakan dana desa pertama kali diimplementasikan pada tahun anggaran 2015 dengan jumlah pengalokasian dana desa sebesar Rp20,7 triliun. Menurut Kementrian Keuangan (2018) penyaluran dana desa terus meningkat dari tahun ke tahun yakni Rp46,98 triliun pada tahun 2016, masing-masing Rp60 triliun pada tahun 2017 dan tahun 2018, Rp70 triliun pada tahun 2019, dan Rp72 triliun pada tahun 2020.

Meskipun sudah didukung oleh dana desa, potensi desa untuk mewujudkan pembangunan dan meningkatkan kesejahteraan masyarakat belum dapat dimaksimalkan karena implementasi penggunaan dan pengelolaan dana desa masih mengalami berbagai kendala terutama terkait sasaran penggunaannya. Peruntukkan dana desa yang tidak sesuai dengan kebijakan yang berlaku bisa menghambat pengelolaan dan penggunaan dana desa, yang mana jika tidak dipantau dan dibenahi maka cita-cita kesejahteraan bangsa Indonesia akan sulit dicapai. Disisi lain, program dana desa merupakan salah satu program pemerintah yang diharapkan mampu memberikan dampak yang besar dan signifikan terhadap kesejahteraan dan pembangunan masyarakat desa.

Berdasarkan pemaparan tersebut, penulis melakukan tinjauan untuk mengetahui implementasi dan manfaat penggunaan dana desa pada suatu desa di Indonesia. Tinjauan atas penggunaan dana desa berfokus pada penggunaan dana desa di Desa Tasik Juang pada tahun 2018, 2019, dan 2020. Penggunaan dana desa di Desa Tasik Juang menjadi hal yang menarik untuk dibahas karena pengelolaan dan penggunaan dana desa di Desa Tasik Juang terlihat belum maksimal terutama dalam bidang pemberdayaan masyarakat. Hal tersebut kurang sesuai dengan Permendesa PDTT Nomor 19 tahun 2017, Permendesa PDTT Nomor 16 tahun 2018, dan Permendesa PDTT Nomor 11 tahun 2019 sebagaimana diubah dengan Permendesa PDTT Nomor 14 tahun 2020, yang menyatakan bahwa salah satu prioritas penggunaan Dana Desa pada tahun 2018, 2019, dan 2020 ialah pemberdayaan masyarakat. Sama halnya dengan penelitian yang dilakukan oleh (Rahayu, 2017) di Desa Kalikayen, diketahui bahwa pengelolaan dana desa di desa tersebut juga belum mampu meningkatkan kesejahteraan masyarakat secara maksimal dikarenakan pengalokasian dana desa hanya ditujukan untuk pembangunan dan perbaikan infrastruktur fisik saja.

Berdasarkan pemaparan tersebut, untuk mengetahui lebih lanjut bagaimana implementasi serta manfaat dana desa terhadap masyarakat Desa Tasik Juang pada tahun 2018-2020, penulis tertarik untuk melakukan penelitian dengan judul: "Tinjauan Atas Penggunaan Dana Desa Di Desa Tasik Juang Tahun 2018-2020". Bagaimana implementasi pengelolaan dan penggunaan dana desa di Desa Tasik Juang pada tahun 2018-2020?.Bagaimana dampak penggunaan dana desa bagi masyarakat di Desa Tasik Juang.

\section{KAJIAN LITERATUR \\ Konsep Dana Desa di Indonesia}

Menurut PMK Nomor 205/PMK.07/2019 tentang Pengelolaan Dana Desa sebagaimana diubah dengan PMK Nomor 40/PMK.07/2020, PMK Nomor 50/PMK.07/2020, dan PMK Nomor 156/PMK.07/2020, dana desa ialah dana yang bersumber dari Anggaran Pendapatan dan Belanja Negara (APBN) yang diperuntukkan bagi desa-desa di Indonesia yang ditransfer melalui Anggaran Pendapatan dan Belanja Daerah (APBD) kabupaten/kota guna membiayai pelaksanaan pembangunan desa, penyelenggaraan pemerintahan desa, pembinaan kemasyarakatan, dan pemberdayaan masyarakat desa. Dana desa disalurkan dari Rekening Kas Umum Negara (RKUN) melalui Rekening Kas Umum Daerah (RKUD) ke Rekening Kas Desa (RKD). Pengalokasian dana desa di Indonesia bertujuan untuk "meningkatkan pelayanan publik di desa, mengentaskan kemiskinan masyarakat desa, memajukan perekonomian desa, mengatasi kesenjangan 
pembangunan antardesa, dan memperkuat masyarakat desa." (Kementerian Keuangan Republik Indonesia, 2017, p. 7).

Dana desa dihitung dari persentase Alokasi Dasar (AD), Alokasi Afirmasi (AA), Alokasi Formula (AF), dan Alokasi Kinerja (AK). Pada tahun 2018 dan tahun 2019, perhitungan rincian dana desa didasarkan pada tiga alokasi yaitu Alokasi Dasar (AD), Alokasi Afirmasi (AA), dan Alokasi Formula (AF). Sedangkan pada tahun 2020, berdasarkan PMK 205/PMK.07/2019 tentang Pengelolaan Dana Desa sebagaimana diubah dengan PMK Nomor 40/PMK.07/2020, PMK Nomor 50/PMK.07/2020, dan PMK Nomor 156/PMK.07/2020, rincian perhitungan dana desa dihitung berdasarkan 4 alokasi yaitu Alokasi Dasar (AD), Alokasi Afirmasi (AA), Alokasi Formula (AF), dan Alokasi Kinerja (AK). Formula Alokasi Kinerja (AK) ditambahkan pada tahun 2020 guna mendorong kinerja pengelolaan dana desa. Bobot formula perhitungan rincian dana desa pada tahun 2018, 2019, dan 2020 dapat dilihat pada tabel 1.

Tabel 1. Perbandingan Rincian Perhitungan Dana Desa Pada Tahun 2018-2020

\begin{tabular}{|l|c|c|c|}
\hline \multicolumn{1}{|c|}{ Formula } & $\mathbf{2 0 1 8}$ & $\mathbf{2 0 1 9}$ & $\mathbf{2 0 2 0}$ \\
\hline Alokasi Dasar & $77 \%$ & $72 \%$ & $69 \%$ \\
\hline Alokasi Afirmasi & $3 \%$ & $3 \%$ & $1,5 \%$ \\
\hline Alokasi Formula & $20 \%$ & $25 \%$ & $28 \%$ \\
\hline Alokasi Kinerja & - & - & $1,5 \%$ \\
\hline
\end{tabular}

Sumber: Diolah dari PMK 226/PMK.07/2017, PMK 193/PMK.07/2018, dan PMK Nomor 205/PMK.07/2019

Berdasarkan PMK 205/PMK.07/2019 tentang Pengelolaan Dana Desa sebagaimana diubah dengan PMK Nomor 40/PMK.07/2020, PMK Nomor 50/PMK.07/2020, dan PMK Nomor 156/PMK.07/2020, Alokasi Dasar (AD) dihitung dari anggaran dana desa yang dibagi secara merata ke setiap desa secara nasional, Alokasi Afirmasi (AA) dihitung dari anggaran dana desa dibagi secara merata kepada desa tertinggal dan desa sangat tertinggal, Alokasi Kinerja (AK) dihitung dari anggaran dana desa yang diberikan kepada desa dengan kinerja terbaik, dan Alokasi Formula (AF) dihitung dari anggaran dana desa yang dibagi berdasarkan indikator jumlah penduduk, angka kemiskinan desa, luas wilayah desa, dan tingkat kesulitan geografis.

\section{Dana Desa di Beberapa Negara}

Skema sejenis dana desa di Indonesia juga dikenal di negara lain meskipun tidak sepenuhnya identik, seperti di negara Laos dan Myanmar (Jamaluddin, et al., 2018). Kebijakan dana desa di Laos disebut dengan Village Development Funds atau VDFs yaitu bantuan fiskal yang berasal dari pemerintah Finlandia dan Bank Dunia (Paavola, 2012 dikutip Jamaluddin et al, . 2018, p. 15). Kebijakan Village Development Funds atau VDFs memiliki tujuan yang sama dengan penyaluran dana desa di Indonesia yaitu untuk mengentaskan kemiskinan terutama di daerah-daerah terpencil seperti desa.

Sedangkan kebijakan dana desa "di Myanmar disebut dengan kebijakan Local Development Funds atau LDFs" (Robertson et al., 2015 dikutip Jamaluddin et al,. 2018, p. 15). Jamaluddin et al,. (2018) mengatakan bahwa tahapan utama dalam kebijakan Local Development Funds (LDFs) ialah tahap perencanaan dan penganggaran oleh pemerintah, yang mana Kebijakan Local Development Funds (LDFs) digunakan untuk mendanai kegiatan pengembangan masyarakat yang dilakukan melalui transfer dana antar-pemerintah. Kebijakan Local Development Funds (LDFs) disesuaikan dengan kebutuhan masyarakat desa, hal tersebut mirip dengan kebijakan dana desa di Indonesia yaitu pengalokasian dana desa yang dilakukan melalui skema bottom-up. Baik kebijakan Local Development Funds (LDFs) di Myanmar maupun 
kebijakan dana desa di Indonesia, tujuan penyesuaian kebutuhan masyarakat utamanya ialah sama yaitu untuk pembangunan infrastruktur sederhana seperti saluran irigasi, jembatan, air minum, dan drainase. "Proyek-proyek Kebijakan Local Development Funds (LDFs) diawasi dan dikelola oleh perwakilan pengelolaan dana tingkat lokal dan pemerintah daerah." (Robertson et al., 2015 dikutip Jamaluddin et al., 2018, p. 15).

Kebijakan Village Development Funds (VDFs) di Laos, Local Development Funds (LDFs) di Myanmar, dan dana desa di Indonesia memiliki persamaan yaitu sama-sama bertujuan untuk meningkatkan kesejahteraan masyarakat. Persamaan lainnya ialah dari segi proses perencanaan kegiatan atau program, kebijakan Local Development Funds (LDFs) di Myanmar dan kebijakan dana desa di Indonesia sama-sama melakukan perencanaan dengan skema bottomup, sedangkan kebijakan Village Development Funds (VDFs) di Laos menggunakan skema gabungan antara bottom-up dengan top-down. Skema bottom-up merupakan pendekatan yang berfokus pada perencanaan yang memberikan kesempatan secara luas kepada masyarakat untuk mengusulkan gagasan dari proses perencanaan hingga evaluasi. Sedangkan skema top-down merupakan pendekatan yang mana segala perencanaan dan keputusan terkait program atau kegiatan ditentukan oleh pihak pemerintah.

\section{Prioritas Penggunaan Dana Desa Tahun 2018-2020}

Prioritas Penggunaan dana desa pada tahun 2018-2020 ialah untuk membiayai pelaksanaan program dan kegiatan pada dua bidang utama yaitu bidang pembangunan desa dan pemberdayaan masyarakat desa. Pada bidang pembangunan desa, dana desa digunakan untuk meningkatkan kualitas hidup masyarakat desa, meningkatkan kesejahteraan masyarakat desa, dan penanggulangan kemiskinan. Sedangkan pada bidang pemberdayaan masyarakat, dana desa digunakan untuk meningkatkan kapabilitas dan kapasitas masyarakat desa melalui pendayagunaan potensi dan sumber daya yang ada sehingga desa bisa menghidupi dirinya secara mandiri.

\section{Penelitian Terdahulu}

Beberapa penelitian terkait dana desa telah dilakukan di beberapa desa di Indonesia. Jamaluddin et al. (2018) melakukan penelitian mengenai analisis dampak pengelolaan dan penggunaan dana desa terhadap pembangunan daerah. Hasil penelitian tersebut meyatakan bahwa pengelolaan dan penggunaan dana desa tidak memberi dampak signifikan bagi pertumbuhan pembangunan daerah dan nyatanya program pembangunan desa tidak sinkron dengan kebijakan Rencana Pembangunan Jangka Menengah Daerah (RPJMD), hal tersebut terjadi karena desa memiliki kewenangan yang luas dalam menentukan rencana program desa sehingga sulit untuk diintegrasikan dengan kebijakan Rencana Pembangunan Jangka Menengah Daerah (RPJMD).

Selain itu, Rainal Mamelo et al. (2016) juga melakukan penelitian tentang pelaksanaan dan penatausahaan dana desa di Desa Moyag dan Desa Kobo Kecil. Hasil penelitian tersebut menyatakan bahwa pelaksanaan dana desa di Desa Moyag dan Desa Kobo Kecil telah dilakukan berdasarkan regulasi namun pelaksanaannya belum sepenuhnya mendukung asas-asas pengelolaan keuangan desa dan juga pemerintah desa tersebut belum memiliki SOP (standard operating procedure) terkait pelaksanaan dana desa.

Rahayu (2017) juga melakukan penelitian terkait strategi pengelolaan dana desa guna meningkatkan kesejahteraan masyarakat. Penelitian tersebut dilakukan di Desa Kalikayen Kabupaten Semarang. Dari penelitian tersebut dapat diketahui bahwa pengelolaan dana desa belum mampu meningkatkan kesejahteraan masyarakat desa karena fokus penyaluran dana desa diutamakan hanya untuk pembangunan dan perbaikan infrasturktur fisik. 


\section{Gambaran Umum Desa Tasik Juang}

Berdasarkan RPJMDes Desa Tasik Juang tahun 2016-2021, Desa Tasik Juang merupakan salah satu desa di kecamatan Lubuk Batu Jaya, Kabupaten Indragiri Hulu, Riau. Desa Tasik Juang terdiri dari tiga dusun yaitu Dusun Lembah Sari, Dusun Bukit Subur Jumlah, dan Dusun Mekar Sari. Total jumlah penduduk Desa Tasik Juang ialah sebanyak 1.227 jiwa dengan rincian laki-laki sebanyak 628 jiwa dan perempuan sebanyak 599 jiwa dengan latar belakang pendidikan SD sebanyak 288 orang, SLTP/sederajat 460 orang, SLTA/sederajat 571 orang, S1/Diploma 176 orang, dan putus sekolah 200 orang.

Dalam menjalankan pemerintahannya, Desa Tasik Juang memiliki struktur organisasi yang sudah mengacu pada Permendagri Nomor 84 tahun 2015 tentang Susunan Organisasi dan Tata Kerja Pemerintah. Struktur organisasi pemerintah Desa Tasik Juang terdiri dari kepala desa, sekretaris desa, kepala urusan umum, kepala urusan keuangan, kepala seksi pemerintahan, kepala seksi kesejahteraan dan pelayanan, dan kepala dusun.

\section{Masalah Desa}

Berdasarkan Peraturan Desa Tasik Juang Kecamatan Lubuk Batu Jaya Kabupaten Indragiri Hulu Nomor 2 tahun 2015 tentang RPJMDes Desa Tasik Juang tahun 2016-2021, tiga bidang yang menjadi permasalahan utama Desa Tasik Juang ialah bidang infrasturktur desa, bidang pendidikan, dan bidang kesehatan. Pada bidang infrastruktur, permasalahan desa yaitu sarana drainase, box culvert, dan jalan desa yang belum memadai. Pada bidang pendidikan, permasalahan desa yaitu kurangnya honorarium guru, kurangnya keterampilan guru dalam mengajar dengan metode baru, belum tersedianya pustaka desa, dan belum lengkapnya sarana dan prasarana pendidikan. Pada bidang kesehatan, permasalahan desa yaitu pelayanan masyarakat yang masih kurang, pemanfaatan posyandu belum optimal serta kesadaran masyarakat akan kesehatan keluarga masih kurang.

\section{METODOLOGI PENELITIAN}

Metode yang digunakan dalam menyusun artikel penelitian ini ialah studi kepustakaan dan wawancara.

A. Metode Studi Kepustakaan

Mengenai pengertian studi kepustakaan, (Sugiyono, 2012, dikutip dalam Yasmin, 2019) menyatakan bahwa:

Studi pustaka berkaitan dengan kajian teoritis dan referensi lain yang berkaitan dengan nilai, budaya dan norma yang berkembang pada situasi sosial yang diteliti, selain itu studi kepustakaan sangat penting dalam melakukan penelitian, hal ini dikarenakan penelitian tidak akan lepas dari literatur-literatur ilmiah. (p. 291)

Metode studi kepustkaaan dilakukan untuk mengetahui adanya kesinambungan antara peristiwa yang terjadi di lapangan dengan kebijakan-kebijakan yang berlaku. Studi kepustakaan yang digunakan yaitu APBDes Desa Tasik Juang Tahun 2018, APBDes Desa Tasik Juang Tahun 2019, APBDes Desa Tasik Juang Tahun 2020, Laporan Realisasi APBDes Tahun 2018, Laporan Realisasi APBDes Tahun 2019, dan Laporan Realisasi APBDes Tahun 2020.

B. Metode Wawancara

Metode wawancara dilakukan oleh penulis sebagai pewawancara dengan responden yaitu perangkat desa dan masyarakat sebagai narasumber untuk mendapatkan informasi penelitian secara langsung. Wawancara dilakukan dengan mengajukan pertanyaan terstruktur yang disusun secara sistematis dan lengkap guna mendapatkan informasi yang dibutuhkan. Penulis melakukan wawancara dengan tiga orang narasumber, yaitu:

1. Informan 1 yaitu Kepala Desa Tasik Juang; 


\section{JURNAL EKOBIS: EKONOMI, BISNIS \& MANAJEMEN}

\section{Vol 11 Nomor 2 (2021)}

2. Informan 2 yaitu warga penerima bantuan renovasi rumah berskala besar; dan

3. Informan 3 yaitu warga penerima bantuan renovasi rumah berskala kecil.

Penulis melakukan wawancara dengan Kepala Desa Tasik Juang karena Kepala Desa Tasik Juang memiliki wewenang, tugas, dan kewajiban menyelenggarakan rumah tangga desa serta memiliki kewajiban untuk melaksanakan tugas dari Pemerintah dan Pemerintah Daerah. Penulis juga melakukan wawancara dengan warga setempat yaitu warga penerima bantuan renovasi rumah karena melalui warga penerima bantuan, penulis bisa mengetahui secara langsung bagaimana pengaruh dana desa terhadap masyarakat. Analisis yang digunakan untuk melihat keterkaitan dana desa dengan dampaknya menggunakan analisis logic model.

\section{HASIL DAN PEMBAHASAN}

\section{Implementasi Penggunaan dana desa di Desa Tasik Juang Pada Tahun 2018-2020}

Sama halnya dengan rencana penyaluran dana desa pada APBDes tahun 2018-2020, realisasi penggunaan dana desa pada tahun 2018-2020 juga mengalami perubahan secara fluktuatif. Rencana penyaluran dana desa pada APBDes tahun 2018-2020 memiliki nilai yang sama dengan realisasi penggunaan dana desa pada tahun 2018-2020. Posisi terendah realisasi pengunaan dana desa terjadi pada tahun 2018 yaitu sebesar Rp679.600.000,00, sedangkan realisasi penggunaan dana desa tertinggi terjadi pada tahun 2019 yaitu sebesar Rp763.371.000,00. Sementara itu, pada tahun 2020 realisasi penggunaan dana desa menurun dari tahun 2019 namun lebih tinggi dari realisasi tahun 2018 yaitu sebesar Rp759.049.000,00. Perbandingan realisasi penggunaan dana desa di Desa Tasik Juang tahun 2018-2020 dapat dilihat pada gambar 1.

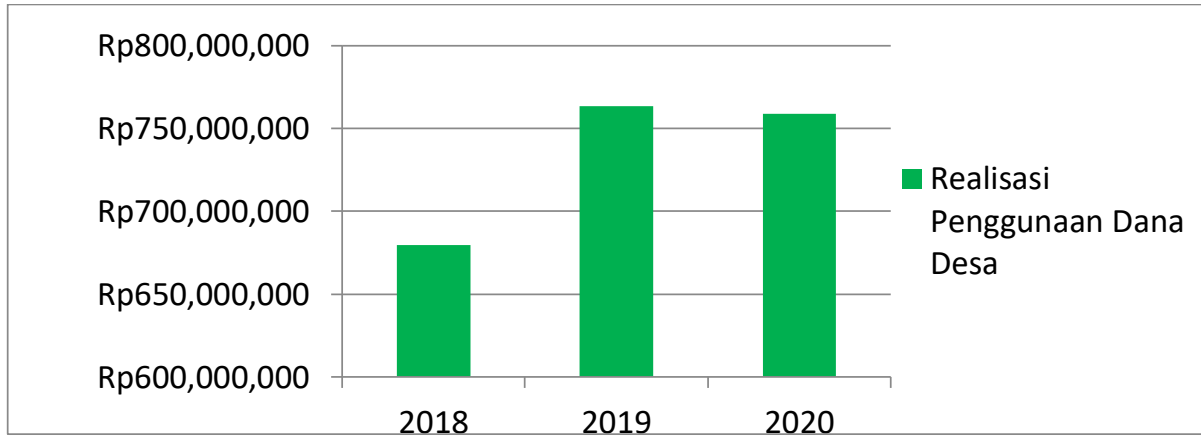

Gambar 1. Realisasi Penggunaan Dana Desa Tahun 2018-2020

Sumber: Diolah dari Laporan Realisasi Pelaksanaan APBDes Desa Tasik Juang Tahun 2018-2020

Pendapatan dana desa di Desa Tasik Juang dari tahun 2018-2020 digunakan untuk belanja pada 4 bidang yaitu bidang pembangunan desa, bidang pemberdayaan masyarakat, bidang pembinaan kemasyarakatan, dan bidang penanggulangan bencana, darurat, dan mendesak. Empat bidang tersebut dialokasikan berdasarkan kebutuhan masyarakat melalui skema bottom-up. Skema bottom-up ialah skema pengalokasian dana desa yang dilakukan berdasarkan anggaran kebutuhan yang diusulkan dari bawah yaitu masyarakat desa. Skema tersebut mirip dengan kebijakan dana desa di Myanmar yaitu kebijakan Local Development Funds (LDFs) yang menyesuaikan pengalokasian dana dengan kebutuhan masyarakat desa.

Pada tahun 2018, realisasi belanja dana desa digunakan untuk belanja pada dua bidang yaitu bidang pembangunan dan bidang pemberdayaan masyarakat, hal ini sudah sesuai dengan Peraturan Menteri Desa, Pembangunan Daerah Tertinggal, dan Transmigrasi Republik Indonesia Nomor 19 tahun 2017 tentang Prioritas Penggunaan Dana Desa Tahun 2018 bahwa prioritas dana desa pada tahun 2018 ialah untuk pembangunan desa dan pemberdayaan masyarakat. Pada tahun 


\section{JURNAL EKOBIS: EKONOMI, BISNIS \& MANAJEMEN}

\section{Vol 11 Nomor 2 (2021)}

2019, realisasi belanja kurang sesuai dengan kurang sesuai dengan Peraturan Menteri Desa, Pembangunan Daerah Tertinggal, dan Transmigrasi Republik Indonesia Nomor 16 tahun 2018 tentang Prioritas Penggunaan Dana Desa Tahun 2019 karena dana desa pada tahun 2019 hanya digunakan untuk belanja di satu bidang yaitu bidang pembangunan desa. Pada tahun 2020, realisasi belanja dana desa digunakan untuk belanja pada tiga bidang yaitu bidang pembangunan desa, bidang pembinaan kemasyarakatan, dan bidang penanggulangan bencana, darurat, dan mendesak. Hal ini sudah sesuai dengan Peraturan Menteri Desa, Pembangunan Daerah Tertinggal, dan Transmigrasi Republik Indonesia Nomor 11 tahun 2019 tentang Prioritas Penggunaan Dana Desa Tahun 2020 sebagaimana telah diubah dengan Peraturan Menteri Desa, Pembangunan Daerah Tertinggal, dan Transmigrasi Republik Indonesia Nomor 6 tahun 2020, Peraturan Menteri Desa, Pembangunan Daerah Tertinggal, dan Transmigrasi Republik Indonesia Nomor 7 tahun 2020, dan Peraturan Menteri Desa, Pembangunan Daerah Tertinggal, dan Transmigrasi Republik Indonesia Nomor 14 tahun 2020.

Perbandingan realisasi belanja dana desa di Desa Tasik Juang tahun 2018-2020 pada bidang pembangunan, pemberdayaan masyarakat, pembinaan kemasyarakatan, dan penanggulangan bencana, darurat, dan mendesak dapat dilihat pada gambar 2.

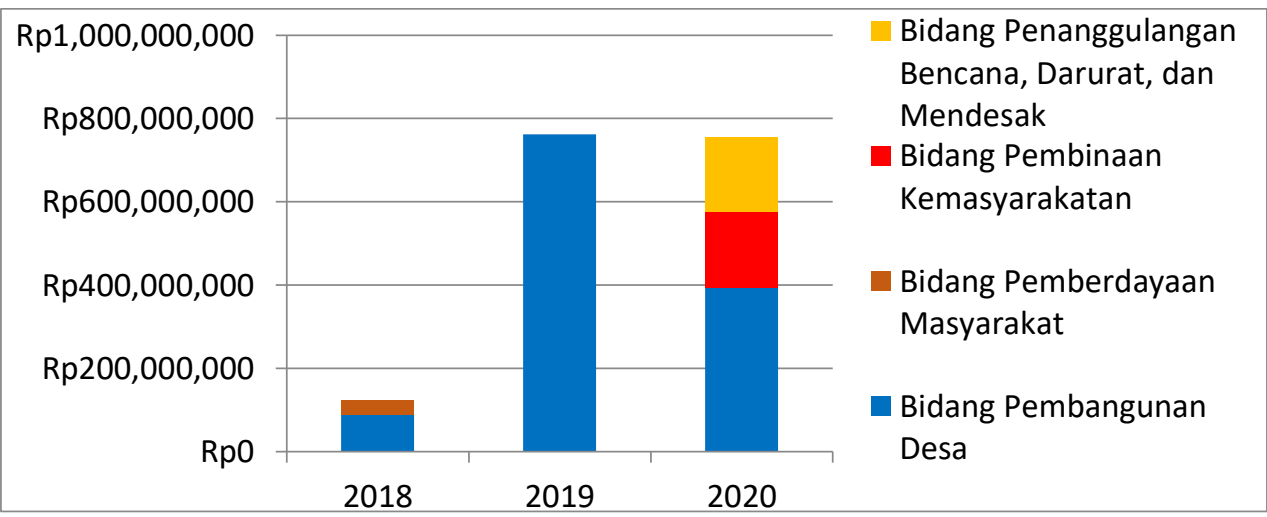

Gambar 2. Realisasi Belanja Dana Desa Tahun 2018-2020

Sumber: Diolah dari Laporan Realisasi Pelaksanaan APBDes Desa Tasik Juang

Tahun 2018-2020

Pada tahun 2018, total belanja penggunaan dana desa ialah sebesar Rp676.347.000,00 untuk belanja di bidang pembangunan desa sebesar Rp637.982.800,00 dan bidang pemberdayaan masyarakat sebesar Rp38.364.200,00. Sementara itu, pada tahun 2019 total belanja penggunaan dana desa ialah sebesar Rp762.808.500,00 hanya untuk belanja di bidang pembangunan desa. Sedangkan pada tahun 2020, total belanja penggunaan dana desa ialah sebesar Rp756.258.700,00 untuk belanja di bidang pembangunan desa sebesar Rp393.971.300,00, bidang pembinaan kemasyarakatan sebesar Rp182.287.400,00, dan bidang penanggulangan bencana, darurat, dan mendesak sebesar Rp180.000.000,00.

Berikut merupakan uraian penggunaan dana desa pada 4 bidang, yaitu:

\section{Bidang Pembangunan Desa}

Pada bidang pembangunan desa, dana desa secara rutin dialokasikan setiap tahunnya dari tahun 2018 hingga tahun 2020. Hal ini sesuai dengan Permendesa PDTT Nomor 19 tahun 2017, Permendesa PDTT Nomor 16 tahun 2018, dan Permendesa PDTT Nomor Nomor 11 tahun 2019 sebagaimana diubah dengan Permendesa PDTT Nomor 6 tahun 2020, Permendesa PDTT Nomor Nomor 7 tahun 2020, dan Permendesa PDTT Nomor 14 tahun 2020 bahwa salah satu prioritas penggunaan dana desa pada tahun 2018-2020 ialah di bidang pembangunan desa. Menurut 


\section{JURNAL EKOBIS: EKONOMI, BISNIS \& MANAJEMEN}

\section{Vol 11 Nomor 2 (2021)}

(Muslihah, et al., 2019), dana desa memberikan dampak terhadap pembangunan dan kesejahteraan masyarakat. Total penggunaan dana desa untuk bidang pembangunan desa ialah sebesar Rp637.982.800,00 pada tahun 2018, sebesar Rp762.808.500,00 pada tahun 2019, dan sebesar Rp393.971.300,00 pada tahun 2020. Rincian penggunaan dana desa pada bidang pembangunan desa pada tahun 2018-2020 dapat dilihat pada tabel 2.

Tabel 2. Penggunaan dana desa pada bidang pembangunan desa pada tahun 2018-2020

\begin{tabular}{|l|r|r|r|}
\hline \multicolumn{1}{|c|}{ URAIAN } & \multicolumn{1}{c|}{$\mathbf{2 0 1 8}(\mathbf{R p})$} & $\mathbf{2 0 1 9}(\mathbf{R p})$ & \multicolumn{1}{c|}{$\mathbf{2 0 2 0}(\mathbf{R p})$} \\
\hline$\underline{\text { Bidang Pembangunan Desa }}$ & $\underline{637.982 .800}$ & $\underline{762.808 .500}$ & $\underline{393.971 .300}$ \\
\hline Pembangunan Sarana Air Bersih & 34.497 .000 & 0 & 0 \\
\hline Penyelenggaraan PAUD/TK/TPA & 0 & 51.000 .000 & 48.000 .000 \\
\hline Dukungan Penyelenggaraan PAUD & 147.705 .300 & 7.963 .300 & 3.815 .500 \\
\hline $\begin{array}{l}\text { Pemeliharaan Sarana Prasarana } \\
\text { PAUD/TK/TPA }\end{array}$ & 0 & 0 & 5.600 .000 \\
\hline $\begin{array}{l}\text { Pembangunan/Rehabilitasi/ } \\
\text { Peningkatan Sarana dan Prasarana }\end{array}$ & 195.363 .400 & 0 & 17.034 .800 \\
\hline Penyelenggaraan Pos Kesehatan & 0 & 31.443 .800 & 0 \\
\hline Penyelenggaraan Posyandu & 0 & 12.671 .500 & 12.900 .000 \\
\hline $\begin{array}{l}\text { Penyelenggaraan Desa Siaga } \\
\text { Kesehatan }\end{array}$ & 0 & 0 & 52.000 .000 \\
\hline Pembangunan Drainase & 0 & 7.000 .000 & 0 \\
\hline $\begin{array}{l}\text { Penyuluhan dan Pelatihan Bidang } \\
\text { Kesehatan }\end{array}$ & 0 & 0 & 14.500 .000 \\
\hline $\begin{array}{l}\text { Penyusunan Dokumen Perencanaan } \\
\text { Tata Ruang Desa }\end{array}$ & 0 & 237.782 .900 & 0 \\
\hline Dukungan Rehab Rumah & 0.417 .100 & 414.947 .000 & 240.121 .000 \\
\hline
\end{tabular}

Sumber: Diolah dari Realisasi Penggunaan Dana Desa di Desa Tasik Juang Tahun 2018-2020

\section{Bidang Pemberdayaan Masyarakat}

Pada bidang pemberdayaan masyarakat, pengalokasian dana desa hanya terjadi pada tahun 2018. Padahal salah satu bidang prioritas penggunaan dana desa pada tahun 2018-2020 selain pembangunan desa ialah pemberdayaan masyarakat. Belanja di bidang pemberdayaan masyarakat tidak dialokasikan pada tahun 2019 dan tahun 2020 karena fokus belanja tahun 2019 hanya pada bidang pembangunan sedangkan pada tahun 2020 belanja difokuskan pada bidang pembangunan dan pembinaan kemasyarakatan. Total realisasi penggunaan dana desa pada bidang pemberdayaan masyarakat pada tahun 2018 ialah sebesar Rp38.364.200,00. Rincian penggunaan dana desa pada bidang pemberdayaan masyarakat pada tahun 2018-2020 dapat dilihat pada tabel 3.

Tabel 3. Belanja Pada Bidang Pemberdayaan Masyarakat

\begin{tabular}{|l|r|r|r|}
\hline \multicolumn{1}{|c|}{ URAIAN } & $\mathbf{2 0 1 8}(\mathbf{R p})$ & $\mathbf{2 0 1 9}$ (Rp) & 2020 (Rp) \\
\hline Bidang Pemberdayaan Masyarakat & $\underline{38.364 .200}$ & 0 & 0 \\
\hline $\begin{array}{l}\text { Kegiatan Pemberdayaan Posyandu, } \\
\text { UP2K dan BKB }\end{array}$ & 17.864 .200 & 0 & 0 \\
\hline Kegiatan Penyuluhan Kesehatan & 13.000 .000 & 0 & 0 \\
\hline $\begin{array}{l}\text { Pengelolaan Kegiatan Pelayanan } \\
\text { Pendidikan dan Kebudayaan }\end{array}$ & 5.000 .000 & 0 & 0 \\
\hline
\end{tabular}


JURNAL EKOBIS: EKONOMI, BISNIS \& MANAJEMEN Vol 11 Nomor 2 (2021)

\begin{tabular}{|c|c|r|r|}
\hline \multicolumn{1}{|c|}{ URAIAN } & $\mathbf{2 0 1 8}(\mathbf{R p})$ & $\mathbf{2 0 1 9}(\mathbf{R p})$ & $\mathbf{2 0 2 0}(\mathbf{R p})$ \\
\hline $\begin{array}{l}\text { Kegiatan Penyusunan Perencanaan } \\
\text { Pembangunan Desa }\end{array}$ & 2.500 .000 & 0 & 0 \\
\hline
\end{tabular}

Sumber: Diolah dari Laporan Realisasi Pelaksanaan APBDes Desa Tasik Juang

Tahun 2018-2020

\section{Bidang Pembinaan Kemasyarakatan}

Penggunaan dana desa untuk belanja di bidang pembinaan kemasyarakatan hanya terjadi pada tahun 2020. Dana desa di bidang pembinaan kemasyarakatan digunakan untuk pembangunan/rehabilitasi/peningkatan sarana dan prasarana sebesar Rp182.287.400,00 berupa pembangunan lapangan voli sebagai sarana olahraga masyarakat Desa Tasik Juang.

\section{Bidang Penanggulangan Bencana, Darurat, dan Mendesak}

Penggunaan dana desa untuk bidang penanggulangan bencana, darurat, dan mendesak hanya terjadi pada tahun 2020 karena pada tahun 2020 terjadi pandemi Covid-19 yang mengharuskan pemerintah termasuk pemerintah desa mengalokasikan dana untuk penanggulangan bencana, darurat, dan mendesak. Pengalokasian dana desa untuk untuk bidang penanggulangan bencana, darurat, dan mendesak pada tahun 2020 digunakan untuk belanja Bantuan Langsung Tunai (BLT) sebesar Rp180.000.000,00. Bantuan Langsung Tunai (BLT) merupakan bantuan yang diberikan oleh pemerintah kepada masyarakat kurang mampu guna menjaga daya beli masyarakat kurang mampu di desa akibat adanya pandemi Covid-19.

\section{Dampak Penggunaan Dana Desa Tahun Anggaran 2018-2020}

Penulis menguraikan dampak penggunaan dana desa tahun 2018-2020 dengan metode logic model. Logic model merupakan metode yang berguna untuk memahami dan memperjelas hubungan sebab-akibat antara input, proses, output, dan outcome suatu program atau kegiatan. Untuk program dana desa tahun 2018-2020, berikut merupakan uraian input, proses, output, dan outcome dengan metode logic model:

a. Input Program Dana Desa Tahun 2018-2020

Input merupakan komponen yang diperlukan dalam suatu program atau kegiatan yang akan diproses untuk menghasilkan output. Input dari kegiatan penggunaan dana desa yang dialokasikan pada tahun 2018-2020 berupa dana desa pada tahun 2018, 2019, dan 2020, sumber daya manusia (SDM) yaitu pemerintah Desa Tasik Juang, dan kebijakan-kebijakan yang berlaku terkait dana desa tahun 2018-2020.

b. Proses Program Dana Desa Tahun 2018-2020

Proses merupakan seluruh kegiatan yang mengubah input menjadi output. Proses dari kegiatan penggunaan dana desa pada tahun 2018-2020 berupa kegiatan pembangunan infrastruktur fisik, penyelenggaraan pemerintahan desa seperti rapat antar perangkat desa, kegiatan pemberdayaan masyarakat desa, kegiatan pembinaan kemasyarakatan, dan pemeliharaan sarana dan prasarana desa.

c. Output Program Dana Desa Tahun 2018-2020

Output merupakan komponen yang dihasilkan dari proses penggunaan atau pemanfaatan input. Dana desa pada tahun 2018 digunakan untuk belanja pada dua bidang yaitu bidang pelaksanaan pembangunan desa dan bidang pemberdayaan masyarakat. Pada bidang pembangunan desa, dana desa digunakan untuk membangun saluran drainase dan pengadaan alat penyedia air bersih. Sedangkan pada bidang pemberdayaan masyarakat, dana desa digunakan untuk pembangunan dua kelas baru di PAUD Nusa Indah dan pembangunan lapangan futsal di RT 07 RW 02 Dusun Bukit Subur. Rincian output penggunaan dana desa di Desa Tasik Juang tahun 2018 dapat dilihat pada tabel 4. 


\section{JURNAL EKOBIS: EKONOMI, BISNIS \& MANAJEMEN}

\section{Vol 11 Nomor 2 (2021)}

Tabel 4. Output Penggunaan Dana Desa Tahun 2018

\begin{tabular}{|l|c|c|}
\hline \multicolumn{1}{|c|}{ Identitas Barang } & $\begin{array}{c}\text { Jumlah/ } \\
\text { Ukuran }\end{array}$ & $\begin{array}{c}\text { Harga Perolehan } \\
\text { (Rp) }\end{array}$ \\
\hline Pembangunan Ruang Kelas Baru PAUD & 2 kelas & 149.182 .290 \\
\hline Pembangunan Lapangan Futsal & $25 \mathrm{~m} \mathrm{x} \mathrm{15} \mathrm{m}$ & 195.424 .850 \\
\hline Alat Penyedia Air Bersih & I unit & 34.497 .000 \\
\hline Drainase RT 04 RW 02 dan RT 06 RW 02 & 600 meter & 262.695 .860 \\
\hline
\end{tabular}

Sumber: Diolah dari buku inventaris aset Desa Tasik Juang tahun 2018

Sementara itu, dana desa pada tahun 2019 digunakan hanya untuk satu bidang yaitu bidang pelaksanaan pembangunan. Bidang pelaksanaan pembangunan terdiri dari beberapa subbidang yaitu subbidang pendidikan, subbidang kesehatan, subbidang pekerjaan umum dan penataan ruangan, dan subbidang kawasan pemukiman. Pada subbidang pendidikan, dana desa digunakan untuk membayar honorarium pengajar PAUD/TK/TPA/TKA/TPQ dan untuk belanja sarana pendukung PAUD. Pada subbidang kesehatan, dana desa digunakan untuk belanja jasa honorarium, belanja modal peralatan khusus kesehatan, dan belanja barang untuk diserahkan kepada masyarakat seperti vitamin dan obat-obatan. Pada subbidang pekerjaan umum dan penataan ruangan, dana desa digunakan untuk belanja barang cetak dan penggandaan, membayar honorarium, dan belanja modal drainase. Sedangkan pada subbidang kawasan pemukiman dana desa digunakan untuk renovasi rumah warga sebanyak 20 rumah. Realisasi output penggunaan dana Desa Tasik Juang tahun 2019 dapat dilihat pada tabel 5.

Tabel 5. Output Penggunaan Dana Desa Tahun 2019

\begin{tabular}{|l|c|c|}
\hline \multicolumn{1}{|c|}{ Identitas Barang } & $\begin{array}{c}\text { Jumlah/ } \\
\text { Ukuran }\end{array}$ & $\begin{array}{c}\text { Harga Perolehan } \\
(\mathbf{R p})\end{array}$ \\
\hline Honor Guru PAUD/TPA/TKA/TPQ/Madrasah & 1 paket & 51.300 .000 \\
\hline Sarana PAUD & 1 paket & 7.963 .300 \\
\hline Obat/Alat KB & 1 paket & 21.000 .000 \\
\hline Makanan Tambahan/Obat/Vitamin & 1 paket & 12.671 .000 \\
\hline Alat Kesehatan & 1 paket & 7.000 .000 \\
\hline Rehab Rumah Warga & 20 rumah & 241.298 .400 \\
\hline Drainase & 800 meter & 414.947 .000 \\
\hline
\end{tabular}

Sumber: Diolah dari RKPDes Desa Tasik Juang Tahun 2020

Sedangkan pada tahun 2020, dana desa digunakan untuk belanja pada tiga bidang yaitu bidang pelaksanaan pembangunan desa, bidang pembinaan kemasyarakatan, dan bidang penanggulangan bencana, darurat, dan mendesak. Pada bidang pelaksanaan pembangunan desa, dana desa digunakan untuk belanja di beberapa subbidang yaitu subbidang pendidikan, subbidang kesehatan, subbidang pekerjaan umum dan penataan ruangan, dan subbidang kepemudaan dan olahraga. Pada subbidang pendidikan, dana desa digunakan untuk membayar honorarium pengajar PAUD/TK/TPA/TKA/TPQ, pemeliharaan gedung dan bangunan PAUD/TK/TPA/TKA/TPQ, dan untuk belanja khusus pendidikan dan perpustakaan. Pada subbidang kesehatan, dana desa digunakan untuk belanja jasa honorarium, belanja modal peralatan khusus kesehatan, belanja barang untuk diserahkan kepada masyarakat, dan belanja ATK. Pada subbidang pekerjaan umum dan penataan ruangan, dana desa digunakan untuk membayar honorarium, belanja barang konsumsi, dan belanja modal drainase. Pada bidang pembinaan kemasyarakatan, dana desa digunakan untuk belanja di subbidang kepemudaan dan olahraga yang menghasilkan bangunan berupa lapangan voli. Pada bidang penanggulangan 
bencana, darurat, dan mendesak, dana desa digunakan untuk belanja penanggulangan bencana akibat pandemi Covid-19 berupa Bantuan Langsung Tunai (BLT). Tabel realisasi output penggunaan dana Desa Tasik Juang tahun 2020 dapat dilihat pada tabel 6.

Tabel 6. Output Penggunaan Dana Desa Tahun 2020

\begin{tabular}{|l|c|c|}
\hline \multicolumn{1}{|c|}{ Identitas Barang } & $\begin{array}{c}\text { Jumlah/ } \\
\text { Ukuran }\end{array}$ & $\begin{array}{c}\text { Harga Perolehan } \\
\text { (Rp) }\end{array}$ \\
\hline Lapangan Voli & $25 \mathrm{~m} \mathrm{x} \mathrm{14} \mathrm{m}$ & 182.287 .400 \\
\hline Drainase RT 08 dan RT 09 Dusun III Mekar Sari & $600 \mathrm{~m} \mathrm{x} \mathrm{0.6} \mathrm{m} \mathrm{x} \mathrm{0.6} \mathrm{m}$ & 254.621 .000 \\
\hline Bantuan Langsung Tunai (BLT) & 50 Orang & 180.000 .000 \\
\hline
\end{tabular}

Sumber: Diolah dari buku inventaris aset Desa Tasik Juang Tahun 2020

\section{d. Outcome Program Dana Desa Tahun 2018-2020}

Outcome merupakan komponen manfaat atau dampak yang dihasilkan dari proses pengubahan input menjadi output. Pada tahun 2018, penggunaan dana desa dialokasikan pada dua bidang yaitu bidang pembangunan dan bidang pemberdayaan masyarakat.

Penggunaan dana desa terbesar pada tahun 2018 dialokasikan untuk menghasilkan output berupa saluran drainase. Penggunaan dana desa untuk pembangunan drainase memberikan dampak positif kepada masyarakat. Sebelum adanya drainase tersebut genangan air limbah rumah tangga dan air hujan sering meluap ke rumah warga dan ke jalan sehingga menimbulkan rasa kurang nyaman bagi masyarakat. Namun, setelah ada pembangunan drainase tersebur, tidak ada lagi luapan air baik itu air hujan maupun air limbah rumah tangga yang mengganggu masyarakat.

Selain berdampak kepada masyarakat yang merasakan langsung manfaat adanya drainase tersebut, pembangunann drainase juga memberi dampak kepada para pekerja yang membangun drainase tersebut. Pemerintah Desa Tasik Juang melaksanakan program Padat Karya Tunai Desa (PKTD) terhadap pembangunan yang dibiayai dengan dana desa salah satunya ialah pembangunan drainase desa. PKTD ialah program pembangunan yang dilakukan dengan memberdayakan masyarakat setempat dengan memberikan upah tunai harian secara langsung kepada masyarakat yang terlibat. Berdasarkan Permendesa PDTT Nomor 14 tahun 2020, dana desa diprioritaskan untuk membiayai program Padat Karya Tunai Desa (PKTD). Program PKTD bertujuan untuk meningkatkan perekonomian, mengurangi tingkat kemiskinan, meningkatkan pendapatan masyarakat, dan menurunkan angka balita stunting. Berkaitan dengan program PKTD, penulis melakukan wawancara kepada kepala desa Tasik Juang. Informan 1 mengatakan:

"Dalam dana desa terdapat kewajiban untuk memberdayakan atau memperkerjakan masyarakat setempat. Ada namanya PKTD yaitu Padat Karya Tunai Desa, jadi pekerjaan desa dikerjakan oleh masyarakat, ketika jam kerja selesai upah kerjanya dibayar tunai langsung hari itu juga, contohnya pada saat pembangunan saluran drainase, pengecorannya dilakukan oleh masyarakat yang membutuhkan pekerjaan" (Informan 1, wawancara, 20 April 2021).

Berdasarkan wawancara tersebut, dapat diketahui bahwa pembangunan drainase yang dibiayai dari dana desa melalui program PKTD menciptakan lapangan kerja baru bagi masyarakat. Artinya, secara tidak langsung PKTD membantu perekonomian masyarakat dan mengurangi tingkat pengangguran. Selain berdampak positif bagi masyarakat yang merasakan langsung manfaat adanya drainase, pembangunan drainase yang menggunakan dana desa juga berdampak positif bagi masyarakat yang terlibat dalam program PKTD. Adapun outcomes penggunaan dana desa pada tahun 2018 dapat dilihat pada tabel 7. 
JURNAL EKOBIS: EKONOMI, BISNIS \& MANAJEMEN Vol 11 Nomor 2 (2021)

Tabel 7. Outcomes Penggunaan Dana Desa Pada Tahun 2018

\begin{tabular}{|c|c|c|c|c|}
\hline \multirow{2}{*}{ Tahun } & \multirow{2}{*}{$\begin{array}{c}\text { Anggaran } \\
\text { (Rupiah) }\end{array}$} & \multicolumn{2}{|c|}{ Output } & \multirow[b]{2}{*}{ Outcome } \\
\hline & & Item & $\begin{array}{l}\text { Jumlah/ } \\
\text { Ukuran }\end{array}$ & \\
\hline \multirow[t]{4}{*}{2018} & 195.424 .850 & Lapangan Futsal & $25 \mathrm{~m} \mathrm{x} 15 \mathrm{~m}$ & $\begin{array}{l}\text { - Meningkatnya produktivitas; } \\
\text { dan } \\
\text { - Terwujudnya masyarakat } \\
\text { sehat. }\end{array}$ \\
\hline & 34.497 .000 & $\begin{array}{l}\text { Alat Penyedia } \\
\text { Air Bersih }\end{array}$ & 1 paket & $\begin{array}{l}\text { - Meningkatnya pelayanan } \\
\text { publik. }\end{array}$ \\
\hline & 149.182 .290 & $\begin{array}{l}\text { Pembangunan } \\
\text { Ruang Kelas } \\
\text { Baru PAUD }\end{array}$ & 2 kelas & $\begin{array}{l}\text { - Meningkatnya efektivitas } \\
\text { proses belajar mengajar. }\end{array}$ \\
\hline & 262.695 .860 & $\begin{array}{c}\text { Drainase RT } 04 \\
\text { RW } 02 \text { dan RT } \\
06 \text { RW } 02\end{array}$ & $600 \mathrm{~m}$ & $\begin{array}{l}\text { - } \text { Berkurangnya risiko banjir; } \\
\text { penurunan tingkat } \\
\text { pengangguran; dan } \\
\text { - meningkatnya perekonomian } \\
\text { masyarakat. }\end{array}$ \\
\hline
\end{tabular}

Sumber: Diolah dari buku inventaris aset Desa Tasik Juang Tahun 2018

Pada tahun 2019 penggunaan dana desa hanya dialokasikan pada bidang pembangunan desa. Adapun outcomes penggunaan dana desa pada tahun 2019 dapat dilihat pada tabel III.10.

Tabel 8. Outcomes Penggunaan Dana Desa Pada Tahun 2019

\begin{tabular}{|c|c|c|c|c|}
\hline \multirow{2}{*}{ Tahun } & \multirow{2}{*}{$\begin{array}{c}\text { Anggaran } \\
\text { (Rupiah) }\end{array}$} & \multicolumn{2}{|c|}{ Output } & \multirow[b]{2}{*}{ Outcome } \\
\hline & & Item & $\begin{array}{l}\text { Jumlah/ } \\
\text { Ukuran }\end{array}$ & \\
\hline \multirow[t]{7}{*}{2019} & 51.300 .000 & $\begin{array}{l}\text { Honor Guru } \\
\text { PAUD/TPA }\end{array}$ & 1 paket & - Meningkatnya kinerja guru \\
\hline & 7.963 .300 & Sarana PAUD & 1 paket & - Lancarnya proses pembelajaran; \\
\hline & 21.000 .000 & $\begin{array}{c}\text { Honor/Obat/ } \\
\text { Alat KB }\end{array}$ & 1 paket & - Pelayanan kesehatan lebih baik \\
\hline & 12.671 .000 & $\begin{array}{l}\text { Obat/Vitamin/ } \\
\text { Makanan } \\
\text { Tambahan } \\
\end{array}$ & 1 paket & $\begin{array}{l}\text { - Terwujudnya masyarakat sehat; } \\
\text { dan } \\
\text { - menurunnya balita stunting }\end{array}$ \\
\hline & 7.000 .000 & Alat Kesehatan & 1 paket & - Pelayanan kesehatan lebih baik. \\
\hline & 241.298 .400 & $\begin{array}{c}\text { Rehab Rumah } \\
\text { Warga }\end{array}$ & 20 rumah & - Terwujudnya rumah layak huni. \\
\hline & 414.947 .000 & Drainase & $800 \mathrm{~m}$ & $\begin{array}{l}\text { - Berkurangnya risiko banjir; } \\
\text { - menurunya tingkat pengangguran; } \\
\text { dan } \\
\text { - peningkatan perekonomian }\end{array}$ \\
\hline
\end{tabular}

Sumber: Diolah dari RKPDes tahun 2020

Pada tahun 2019, selain pembangunan drainase, belanja pada bidang pembangunan desa yang membutuhkan biaya yang cukup besar ialah belanja kegiatan rehab rumah warga. Berdasarkan Permendesa PDTT Nomor 16 tahun 2018 tentang Prioritas Penggunaan Dana Desa Tahun 2019, dana desa bisa digunakan untuk pembangunan rumah layak huni di desa. Pada tahun 2019, pemerintah desa Tasik Juang mengalokasikan dana desa untuk merehab 20 rumah warga. 


\section{JURNAL EKOBIS: EKONOMI, BISNIS \& MANAJEMEN}

\section{Vol 11 Nomor 2 (2021)}

Tujuan dilakukannya rehab rumah warga ialah untuk meningkatkan kualitas lingkungan dan mewujudkan rumah layak huni. Berkaitan dengan kegiatan rehab rumah warga, penulis melakukan wawancara kepada dua warga desa Tasik Juang yang menerima bantuan tersebut. Informan 2 yang merupakan penerima dana desa dalam bentuk rehab rumah layak huni berskala besar mengatakan:

"Kita menerima bantuan dana desa tersebut bukan dalam bentuk uang cash namun dalam bentuk bahan baku material, setelah rumahnya jadi baru serah terima. Program ini sangat membantu saya karena kalau saya sendiri yang membangun, saya tidak akan mampu. Program pemerintah yang disalurkan ke masyarakat kurang mampu berupa rehab rumah agar layak huni sudah terealisasi semua dan benar-benar sangat membantu kami" (Informan 2, wawancara, 19 Mei 2021).

Selanjutnya informan 3 sebagai penerima dana desa dalam bentuk rehab rumah layak huni berskala kecil mengatakan:

"Rumah ini hanya dilakukan rehab berupa penggantian papan pembatas dan pintu depan rumah. Papan pembatas diganti dengan yang baru dikarenakan papan pembatas kami yang lama sudah lapuk namun sebenarnya rehab ini tidak ada pengaruhnya. Saya sudah mengajukan kepada pemerintah desa untuk melakukan pembangunan rumah layak huni permanen untuk rumah ini dan pemerintah desa sudah menyetujui namun belum tahu pastinya kapan rehab rumah berupa pemb

angunan rumah layak huni akan dilakukan" (Informan 3, wawancara, 19 Mei 2021).

Berdasarkan keterangan tersebut, dapat diketahui bahwa rehab rumah layak huni berskala besar berdampak positif dan sangat berpengaruh bagi warga penerima bantuan. Bantuan tersebut sangat membantu warga penerima untuk memiliki rumah layak huni, jika tidak ada program tersebut maka warga penerima merasa tidak mampu untuk memiliki rumah layak huni. Di sisi lain, penggunaan dana desa untuk rehab rumah berskala kecil tidak terlalu berpengaruh bagi warga penerima karena rehab yang dilakukan hanya dalam skala kecil, seperti halnya informan 3 katakan bahwa pemerintah desa hanya melakukan rehab berupa penggantian papan pembatas kamar dan satu pintu depan rumah.

Pada tahun 2020, penggunaan dana desa dialokasikan pada tiga bidang yaitu bidang pembangunan desa, bidang pembinaan kemasyarakatan, dan bidang penanggulangan bencana, darurat, dan mendesak. Adapun outcomes penggunaan dana desa pada tahun 2020 dapat dilihat pada tabel 9.

Tabel 9. Outcomes Penggunaan Dana Desa Pada Tahun 2020

\begin{tabular}{|c|c|c|c|c|}
\hline \multirow{2}{*}{ Tahun } & \multirow{2}{*}{$\begin{array}{c}\text { Anggaran } \\
\text { (Rupiah) }\end{array}$} & \multicolumn{2}{|c|}{ Output } & \multirow[b]{2}{*}{ Outcome } \\
\hline & & Item & $\begin{array}{c}\text { Jumlah/ } \\
\text { Ukuran }\end{array}$ & \\
\hline \multirow[t]{3}{*}{2020} & 182.287 .400 & Lapangan Voli & $25 \mathrm{~m} \times 14 \mathrm{~m}$ & $\begin{array}{l}\text { - Meningkatnya roduktivitas, dan } \\
\text { - Terwujudnya masyarakat sehat. }\end{array}$ \\
\hline & 254.621 .000 & \begin{tabular}{|c} 
Drainase RT 08 \\
dan RT 09 \\
Dusun III \\
Mekar Sari
\end{tabular} & $\begin{array}{c}600 \mathrm{~m} \times 0,6 \\
\mathrm{~m} \times 0,6 \mathrm{~m}\end{array}$ & 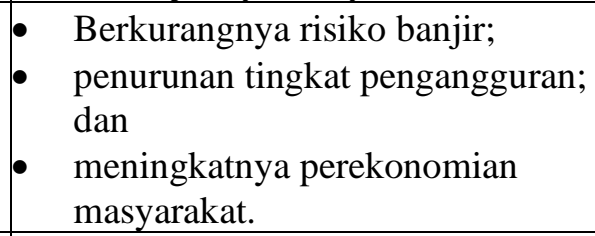 \\
\hline & 180.000 .000 & BLT & 50 orang & $\begin{array}{l}\text { Meningkatkan daya beli } \\
\text { masyarakat }\end{array}$ \\
\hline
\end{tabular}

Sumber: Diolah dari buku inventaris aset Desa Tasik Juang Tahun 2020 
Dari seluruh tabel outcomes pada tahun 2018-2020, dapat diketahui bahwa penyaluran dana desa pada tahun 2018-2020 di bidang pembangunann desa, pemberdayaan masyarakat, pembinaan masyarakat, dan penanggulangan bencana, darurat, dan mendesak, secara garis besar memberikan dampak positif terhadap masyarakat Desa Tasik Juang.

Keterkaitan input, proses, output, dan outcomes program dana desa di Desa Tasik Juang mewujudkan tujuan utama program dana desa yaitu untuk meningkatkan kesejahteraan masyarakat dan meningkatkan ekonomi masyarakat desa. Hal tersebut sesuai dengan penelitian yang dilakukan oleh Sofianto (2017) tentang bagaimana pengaruh pemberian dana desa terhadap pembangunan dan masyarakat desa di Kebumen dan Pekalongan. Penelitian tersebut dilakukan di beberapa Desa di Kecamatan Kajen dan Kecamatan Paninggaran. Melalui penelitian tersebut dapat diketahui bahwa masyarakat dan pemerintah desa di Kecamatan Kajen dan Kecamatan Paninggaran terbantu dengan adanya penyaluran dana desa, terutama dalam bidang pembangunan desa baik dari segi perekonomian maupun sosial dan politik. Hubungan input, proses, output, dan outcome dari program dana desa di Desa Tasik Juang pada tahun 2018-2020 dapat dilihat pada gambar 3.

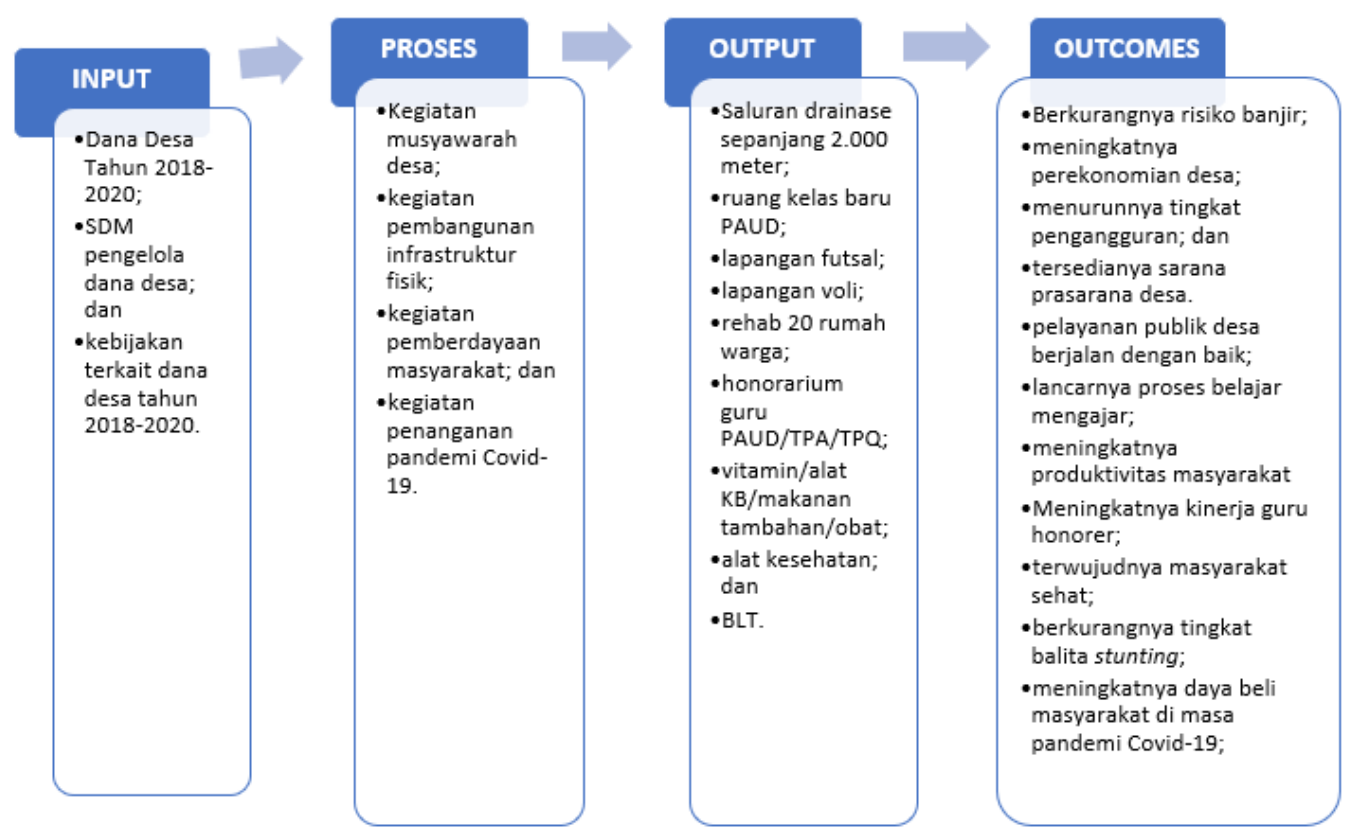

Gambar 3. Logic Model Program Dana Desa Tahun 2018-2020

Sumber: Diolah oleh penulis 


\section{PENUTUP}

Simpulan

Implementasi penggunaan dana desa pada tahun 2018 sudah sesuai dengan prioritas penggunaan dana desa yang tercantum dalam Permendesa PDTT Nomor 19 tahun 2017 yang mana dua bidang prioritas tersebut ialah bidang pembangunan desa dan pemberdayaan masyarakat. Sedangkan pada tahun 2019 dan 2020, implementasi penggunaan dana desa tidak sepenuhnya sesuai dengan prioritas penggunaan dana desa yang tercantum dalam Permendesa PDTT Nomor 16 tahun 2018 dan Permendesa PDTT Nomor 11 tahun 2019 sebagaimana diubah dengan Permendesa PDTT Nomor 14 tahun 2020. Hal ini dikarenakan pada tahun 2019 dan 2020, dana desa tidak diimplementasikan pada bidang pemberdayaan masyarakat, padahal bidang pemberdayaan masyarakat merupakan salah satu prioritas penggunaan dana desa pada tahun 2019 dan 2020.

Jika dijabarkan dengan metode logic model, penggunaan dana desa di Desa Tasik Juang tahun 2018-2020 mulai dapat memberikan hasil lebih dari sekadar keluaran (output) saja namun juga pada dampak (outcome). Secara keseluruhan, implementasi penggunaan Dana desa di Desa Tasik Juang pada tahun 2018-2020 memberikan dampak yang baik terhadap pembangunan desa dan kesejahteraan masyarakat.

\section{REFERENSI}

Jamaluddin, Y., Sumaryana, A., Rusli, B. \& Buchari, R. . A., (2018). Analisis Dampak Pengelolaan dan Penggunaan Dana Desa terhadap Pembangunan Daerah. JPPUMA: Jurnal Ilmu Pemerintahan dan Sosial Politik UMA, pp. 22-23.

Kementerian Keuangan Republik Indonesia, (2017). Buku Saku Dana Desa. Dalam: Jakarta: s.n., p. 7.

Kementrian Keuangan, (2018). Akumulasi Penyaluran Dana Desa Hingga Tahun 2018 Tahap 2 Mencapai Rp149,31 Triliun. [Online] Available at: https://www.kemenkeu.go.id/publikasi/berita/akumulasipenyaluran-dana-desa-hingga-tahun-2018-tahap-2-mencapai-rp149-31-triliun/

Lai, Y. \& Xiaoling Zhang, (2016). Redevelopment of Industrial Sites in The Chinese 'Villages in the City': an Empirical Study of Shenzhen. Journal of Cleaner Production, Volume 134, pp. 70-77.

Muslihah, S., Siregar, H. O. \& S., (2019). DAMPAK ALOKASI DANA DESA TERHADAP PEMBANGUNAN DAN KESEJAHTERAAN MASYARAKAT DESA DI KABUPATEN BANTUL DAERAH ISTIMEWA YOGJAKARTA. Jurnal Akuntansi, Ekonomi dan Manajemen Bisnis, Volume 7, p. 92.

Rahayu, D., (2017). Strategi Pengelolaan Dana Desa untuk Meningkatkan Kesejahteraan Masyarakat Desa Kalikayen Kabupaten Semarang. Economics Development Analysis Journal, p. 116.

Rahma, D. N., (2020). Efektivitas Penggunaan Dana Desa Di Desa Banjarnegoro, Kecamatan Mertoyudan, Kabupaten Magelang, Tangerang Selatan: s.n.

Rainal Mamelo, G. Y., Kalangi, L. \& Lambey, L., (2016). ANALISIS PELAKSANAAN DAN PENATAUSAHAAN DANA DESA PADA DESA-DESA. JURNAL RISET AKUNTANSI DAN AUDITING "GOODWILL", p. 156.

Rusli, B., (2014). Kebijakan Publik: Membangun Pelayanan Publik yang Responsif. Bandung: Adoya Mitra Sejahtera.

Sofianto, A., (2017). Kontribusi Dana Desa Terhadap Pembangunan dan Pemberdayaan Masyarakat di Kebumen dan Pekalongan. Matra Pembaruan: Jurnal Inovasi Kebijakan, p. 31. 
Yasmin, F. N., (2019). TINJAUAN ATAS PEMBERIAN REWARD AND PUNISHMENT PADA KEMENTERIAN / LEMBAGA BIDANG POLITIK, HUKUM, PERTAHANAN, DAN KEAMANAN TAHUN 2017-2019, Tangerang Selatan: s.n.

\section{Peraturan Perundang-undangan}

Pemerintah Republik Indonesia. 2014. Undang-Undang Republik Indonesia Nomor 6 Tahun 2014 tentang Desa.

. 2020. Peraturan Menteri Keuangan Republik Indonesia Nomor 156/PMK.07/2020 tentang Perubahan Ketiga atas Peraturan Menteri Keuangan Nomor 205/PMK.07/2019 tentang Pengelolaan Dana Desa.

.2019. Peraturan Menteri Keuangan Republik Indonesia Nomor 205/PMK.07/2019 tentang Pengelolaan Dana Desa sebagaimana diubah dengan PMK Nomor 156/PMK.07/2020, PMK Nomor 40/PMK.07/2020, PMK Nomor 50/PMK.07/2020

2017. Peraturan Menteri Desa, Pembangunan Daerah Tertinggal, dan Transmigrasi Republik Indonesia Nomor 19 tahun 2017 tentang Penetapan Prioritas Penggunaan Dana Desa Tahun 2018.

2018. Peraturan Menteri Desa, Pembangunan Daerah Tertinggal, dan Transmigrasi Republik Indonesia Nomor 16 tahun 2018 tentang Penetapan Prioritas Penggunaan Dana Desa Tahun 2019.

. 2020. Peraturan Menteri Desa, Pembangunan Daerah Tertinggal, dan Transmigrasi Republik Indonesia Nomor 11 tahun 2019 tentang Prioritas Penggunaan Dana Desa Tahun 2020 sebagaimana telah diubah dengan Peraturan Menteri Desa, Pembangunan Daerah Tertinggal, dan Transmigrasi Republik Indonesia Nomor 6 tahun 2020, Peraturan Menteri Desa, Pembangunan Daerah Tertinggal, dan Transmigrasi Republik Indonesia Nomor 7 tahun 2020, dan Peraturan Menteri Desa, Pembangunan Daerah Tertinggal, dan Transmigrasi Republik Indonesia Nomor 14 tahun 2020. 